\title{
DISCOURSAL STUDY ON RENAISSANCE AND CLASSICAL PAINTINGS IN MICHEL FOUCAULT'S ARCHEOLOGICAL THOUGHT WITH EMPHASIS ON CONCEPTS OF "MADNESS" AND "REPRESENTATION"
}

\author{
Arash Eghbal Jahromi
}

Shamsolmoluk Mostafavi

\begin{abstract}
Regarding art and its function, Foucault believes that it is created in relation to various sciences, organizations and other institutions of a society. Accordingly, he is not after the author's intention or a final meaning within the work when faces neither a work of art, nor he believes in a theory like "art for art's sake", which considers art as separated from the social context. Rather, he intends to analyze why and how a work is allocated to a special content? Or why a work could not be something different from what it is?. In other words, how the work of art becomes what it is in relation to other sciences and social institutions, and it is due to this functions that Foucault considers the artwork as a representative of a historical period; as he regards the painting "Las Meninas" by Velazquez as a representative of the classical era mindset, and also Hieronymus Bosch's "The Ship of Fools" as a reflection of the concept of madness in the Renaissance era. By an emphasis on the writings of Michel Foucault's archeological period of thought - specially "The history of Madness" and "The Order of Things" - this article attempts to study the drawings which he analyzes in relation to other sciences and institutions. Therefore, the present article takes the drawings of the Renaissance and classical era into consideration regarding to Michel Foucault's ideas.
\end{abstract}

Keywords: discourse, representation, madness, renaissance, classic

\section{INTRODUCTION HIERONYMUS BUSH AND MADNESS DISCLOSURE IN THE RENAISSANCE}

Foucault considers art as a statement ${ }^{1}$ that can display dominant episteme on an era. According to this belief, he has investigated artistic works in relation with other statements and subjects to be able to recognize existing actions and interaction sin a historical context and obtain the relations that can lead to formation of an episteme. Hence, artistic work is not considered separated from other statements. However, it has specific features compared to other statements. The specific feature is picturing intellectual space (episteme) of a historical period. For example, Velázquez's Las Meninas is called as the representative of dominant attitude on Classic Era.

According to the attitude, in order to gain unit of discourse ${ }^{2}$ in certain field such as psychology, biology or art or to investigate a specific subject such as madness during a historical period, one can study relations of statements of that era and gain a function of a statement. According to the discussions presented by Foucault in his discourse thought, he doesn't believe that a subject can be formed in certain time and can progress over the history. According to the principles, attention of Foucault was gained by

${ }^{1}$ Statement: according to Foucault, every meaningful issue is a statement. Hence, he has called artistic works as statements.

${ }^{2}$ Foucault has considered unity of discourse as the process of changes in a subject, regardless of considering the changes interrelated or progressive.

Submit Date: 11.06.2016, Acceptance Date: 15.07.2016, DOI NO: 10.7456/1060AGSE/056

Copyright $\mathbb{C}$ The Turkish Online Journal of Design, Art and Communication 
the issue of madness and he indicates in assessment of changes and evolutions of the subject in "Madness History" that how a statement (madness) gains meaning in relation with other statements and gains different functions. He has indicated in this book that the subject of madness has possessed unique meaning in the Renaissance, which is absolutely different from attitude of other periods in regard with the issue, as a result of actions and interactions of different statements and subjects. As it is clear, a psychological attitude is dominated on madness in the modern age and the phenomenon is considered in relation to institutes such as madhouse. However, according to discourse notion of Michel Foucault who tends to indicate ruptures over different ages, the phenomenon has a completely different meaning In the Renaissance compared to attitude of the current age.

In order to demonstrate the evolutions about madness and to indicate epistemological ruptures, Foucault has studied documents and evidence gained from Renaissance. One of the most important statements indicating madness and its function in Renaissance is Painting by Hieronymus Bush as "The Mad Ship" (painting No.1). In order to understand the painting, Foucault has studied different documents and evidence including political, literary and religious works. In fact, he has been aimed in discovering the inter-statement relationship that caused formation of madness phenomena with its specific historical meaning. In these documents, Foucault found that placed where mad people used to be maintained were places that in pre-Reissuance age, lepers used to be sent there to be isolated from other people. He refers that scope of Christian had about 19000 houses for lepers. However, a very important issue is that isolating lepers from ordinary people used to give them divine holiness and demonstrate the presence of God. In Vienna Church, the they used to read this statement for lepers: "My friend! This has been the intention of God that you suffer from such pain. God has punished you because of your bad actions at the world. In fact, God has presented his infinite thanks to you" ${ }^{3}$. Another evidence to prove this important subject is Pieter Brueghel ${ }^{4}$ painting titled "Journey to Calvary". In this painting, those lepers are pictures that are holy sign of devil in view of Foucault, so that people watch rise of Christ and his followers to Calvary Hill ${ }^{5}$.

At the end of Medieval, leper houses were emptied and Foucault believes that this has been the result of actions and interactions of discourse and not finding a treatment method to treat lepers. It means that rejecting them from the society could decline their population, with emptying the houses at the end of Medieval, mad people, the poor and homeless and criminal people replaced instead of them and same as Medieval, the rejection used to bring them redemption for both rejected people and rejecters ${ }^{6}$. In fact, madness was a way to join to population of church and the holy thought was used this time for mad people.

In Renaissance, "The Mad Ship" was common and it had possessed not only paintings, but also content of literary works and political declarations. By that time, The Mad Ship had derived its content from Journey of Argunts ${ }^{7}$ and gained in Renaissance another meaning as a result of inter-statement relations. Many authors like Symphorien Shampier, Jacob Van Stforen and Josse Bade have considered the content in their works by that time. Foucault has considered political evidence in addition to literary and artistic works and has found that by 1399 at Nurnberg, several sailors were taken to service to clean the city from mad people. They used to transit the mad people by ship. However, an important issue here is that taking them out of city has not been for security and this issue has been a ritual issue. This is because; places like

${ }^{3}$ Foucault, 2006: 11

${ }^{4}$ Flamany painter in the 16 th century depicting man's tragic situation

${ }^{5}$ Ibid, 11

${ }^{6}$ Ibid, 12

${ }^{7}$ The Greek mythology heroes who were aboard the ship in search of the legendary Fleece Submit Date: 11.06.2016, Acceptance Date: 15.07.2016, DOI NO: 10.7456/1060AGSE/056 Copyright (C) The Turkish Online Journal of Design, Art and Communication 
Saint-mathurin and Gheel village have been places to trap the mad and were also pilgrimage places. Hence, they had a symbolic ship: "symbolic ships to transit the mad seeking wisdom" ${ }^{8}$.

The iterative content of madness in literary works and political documents refer to a unit discourse in view of Foucault. He says: "the imagination was apparently be cleared by the mad in a very homogeneous and uniform manner in different imaginary and literary fields. Painting and writing used to take inspiration from each other and affect each other constantly; here image and there picture" ${ }^{9}$. Narration of unit content in literary and painting works indicates that there is certain discourse configuration that can form specific attitude to madness in renaissance, in which madness is parallel to divine order and another important issue is that the mad person has been considered as wise person with abilities that ordinary people had no access to them. Hence, in painting of Hieronymus Bush, Tree of Knowledge at the Garden of Eden is cut and tower of the mad ship is made. Only mad people could have eternity of knowledge and wisdom person was only a part of the knowledge ${ }^{10}$.

\section{GREAT IMPRISONMENT AND ARTWORK}

Madness has absolutely different concept by the other periods and in relation with other statements and subjects. For example, by 1657 that is mentioned by Foucault as "Great Imprisonment", a public hospital was established following order of king and a new form of discourse and social institute was formed ${ }^{11}$. According to new emerged institutes, the mad people used to be cared to meet dangers threating they would be imprisoned for this purpose. This issue indicates that madness was not holy anymore and the new reaction to the mad that was sign of new discourse led to production of different artistic works about madness. The different content can be observed in works of Francisco and Marquis de Sade. Foucault believes that due to the imposed imprisonment applied on these people by power institutes in classic era, the mad were imprisoned behind closed and tall doors of asylums and no sound could reach their ears and their soul's cry could be heard just in works of artists like Goya and Marquis de Sade ${ }^{12}$ (figure 2).

\section{MADNESS OF DON QUIXOTE AND BREAK FROM THE RESEMBLANCE SYSTEM}

Foucault has detected another type of madness in classic era and has presented it in relation to typology. He believes that in renaissance, resemblance had formed Western Culture and Thought. Land used to reflect the sky and plants used to hide some secrets in their stems that were useful for people ${ }^{13}$. This issue is demonstrated in painting as the technique of perspective, so that painters used to picture the world similar to what they could see. In fact, the world of arts was seeking resemblance with the outside nature based on discourse system of that time. According to resemblance system by that era, objects used to be considered as objects to be similar to other objects and the resemblance between objects used to form a chain in the world ${ }^{14}$.

It should be mentioned that how the resemblances could be explored? Foucault believes that existence of signatures on objects could enable the resemblance between them. Now, the question is that what are signatures in renaissance? In fact, signatures were things that could visualize resemblances. The signatures were present in surface of objects and resolution of resemblances could be observed through them. For example, resemblance of walnut with human brain could be considered and this was the reason that they believed that walnut is useful to kill headache. This indicates that perception system of renaissance is nothing other than a system of resemblances. Hence, language used to be considered

\footnotetext{
${ }^{8}$ Ibid, 15

${ }^{9}$ Ibid, 24

${ }^{10}$ Refer to Smart, 2006, 23

${ }^{11}$ Dreyfus and Rabinow, 2010: 66

${ }^{12}$ Foucault, 2006: 7

${ }^{13}$ Foucault, $1994: 18$

${ }^{14}$ Tanke,2009: 24
}

Submit Date: 11.06.2016, Acceptance Date: 15.07.2016, DOI NO: 10.7456/1060AGSE/056

Copyright (C) The Turkish Online Journal of Design, Art and Communication 
similar to objects and a reality was also considered for it. This is because; in this thought, language was present in system of resemblances and signatures of the world and hence, it was considered as an object ${ }^{15}$.

In this field, Foucault believes that signatures are mirror, in which the objects shine and reflect their image on another object ${ }^{16}$. Hence, seeking to find a meaning is transparency of a resemblance. Seeking the rule dominated on signatures is exploration of objects that are similar to each other ${ }^{17}$.

The mentioned issues have been presented in regard with semiotic system of renaissance to recognize the existential reason of perspective in painting of that era and to analyze the difference of knowledge system of renaissance and classic era based on signatures. In classic era, the resemblance system was not dominated and language was not considered as an object, but also language possessed another position and was considered as signature of representation of objects. Therefore, the separation between language and the world was happened ${ }^{18}$.

With the beginning of classic era, a dual system of Signifier and signified was formed and language was considered as a representative that was referred to the surrounding environment; although it had no resemblance with the world anymore. The question here is that according to worldview of classic era, how language could communicate the thing referred to it? To answer the question and to clear meaning of representation in Classic Era, character of Don Quixote should be considered. The character is considered as the boundary between the classic and renaissance world by Foucault. Don Quixote is considered as a passenger who announces the end of the age of resemblances. The boundary represented by Don Quixote is in fact an mediate boundary that has not passed through the world of resemblances and has not completely entered the domain of differences (classic era). Foucault says about Don Quixote that his existence is the language and nothing can form his existence other than proses and stories that are published previously. In other words, he is same words. If the novel of Don Quixote is emerged in classic episteme, this is because in novel, pitiless wisdom based on identities and differences ridicules the instrument and nature of renaissance episteme including resemblances and signatures ${ }^{19}$.

Don Quixote tends to prove that he has is same with the signatures of the book, with which he is created. This is because; he has not passed the world of resemblances of renaissance completely. On one hand, he seeks to prove his likeness with signatures of his book and on the other hand, at the same time that he tends to show the likeness, this decision refers to this issue that Don Quixote is at a world that readable signatures are not like tangible people anymore. All proses are unique and nothing at the world is like them $^{20}$. In his world, likeness is destroyed and Foucault has stated in this regard that all of these stories can be burnt in their integrity without changing the physic of the world ${ }^{21}$. Don Quixote tends to return the destroyed attachment between likenesses and signatures. Searching the likeness that used to form knowledge structure of the age in former discourse is considered as madness in time of Don Quixote ${ }^{22}$. Lingual signatures placed in ages of book have not harmony with the natural environment, but also they are just same story that is represented. It could be mentioned that language in has entered a domain in classic era and has been separated from attachment to objects. Don Quixote is a character that is confused in this separation and is searching nostalgically the likenesses.

\footnotetext{
${ }^{15}$ Tanke,2009: 26

${ }^{16}$ Foucault, 1994: 27

${ }^{17}$ Foucault, 2010: 76

${ }^{18}$ Refer to Foucault, 2006: 24

${ }^{19}$ Gat and Lewis, 2007: 67

${ }^{20}$ Foucault, 2010, 106

${ }^{21}$ Ibid, 106

${ }^{22}$ Refer to: Foucault, 2006: 37

Submit Date: 11.06.2016, Acceptance Date: 15.07.2016, DOI NO: 10.7456/1060AGSE/056 Copyright (C) The Turkish Online Journal of Design, Art and Communication
} 
In the second part of his story, Don Quixote faces some characters that have read first part of his novel and know him as a hero. Here, an important issue is that the book is referred to its own and has narrated its own. Don Quixote is changed into his book and has no reality other than it. With the analysis, Foucault discriminated system of differences in classic era. The Don Quixote, who was a real existence based on knowledge system of renaissance, is now change into language and is separated from outside reality ${ }^{23}$. An important issue about Don Quixote and his relationship with representation system of classic era is that Don Quixote has not read his book and can't read it, since he is the book itself. According to classic knowledge, the person that the drama is existed form him/her or represents him/herself in it or someone who has integrated all fields of drama can't be found in the representation ${ }^{24}$. Therefore, Don Quixote can't read his story, since he is represented through language. The thing known as Don Quixote is derived from his attachment with language. He is changed into same language separated from objects that represent its reality and brings new era, in which Foucault has called it as representation system (classic era).

In classic era, mad people are individuals confused in game of similarities and differences and according to analysis of Don Quixote, he is considered as a mad person because of lack of recognizing differences, since he thinks about similarities contrary to classic knowledge era and thinks that all signatures are same.

\section{SIGNATURE REPRESENTATION IN CLASSIC ERA}

In thinking atmosphere of classic era, signatures could be defined based on 3 types of relationship: 1certainty of relationship: a signature may have such explicitness and certainty that ensures person like breathing that is a signature for living; 2- type of relationship: a signature may inform about a whole as a part of whole like physical health that is signature for living health; 3- origin of relationship: a signature can be a contract like a word that can be considered as a signature for a specific group. As it is obvious, contrary to renaissance attitude, the relations are not based on resemblance, but also they can be regarded just as signatures that represent something. The 3 types of relationship are replaced instead of resemblance system and intellectual system of classic era $^{25}$.

In renaissance, signatures, whether known or unknown, were existed, since they were on the objects and their presence or absence was not related to exploring them by human. However, by $17^{\text {th }}$ century (classic era), no unknown signature was existed; since human could make them and use them as an alternative for something. Hence, classic era gains implied function. Therefore, signature in classic era is also a signifier and is not same as signified, but represents $i^{26}$.

Foucault has considered the most important feature of signature in classic era the gap between signature and the signified. This indicates that in classic era, no relationship was existed between the signifier and signified. In fact, signature and the signifier are not same. The factor that relates signifier and signified is an issue associated with classic knowledge and according to it, signature can just represent and an important issue is that the issue (signified) can never be observed in signature. This is because; in classic thought, the person for him/her representation was performed had no position in classic order table. In epistemic space if classic era, there was nowhere for human as the object of knowledge and there was also no epistemological information about human ${ }^{27}$.

In classic thought, two conditions are hidden: first, to be considered as a signature, it should do representation and second, representation happens in signature itself. An important issue here is that the signified is clear juts in representation and the signifier is same thing that is represented. According to this issue that in classic thought, the thing for which representation is done is absent and hence, the only thing

${ }^{23}$ Refer to: Foucault, 2010: 19

${ }^{24}$ Dreyfus and Rabinow, 2010: 95

${ }^{25}$ Refer to: Foucault, 2010: 125

${ }^{26}$ Refer to: Dreyfus and Rabinow, 2010: 86

${ }^{27}$ Foucault, 1994,309

Submit Date: 11.06.2016, Acceptance Date: 15.07.2016, DOI NO: 10.7456/1060AGSE/056

Copyright (C) The Turkish Online Journal of Design, Art and Communication 
that can be represented is representation action. In other words, signified is nothing other than same representation action. As a result, the image would be nothing other than representation action and signified can be recognized as the signified in through the representation action. Hence, in renaissance, the thing represented is never clear. This is because; representation is an action that happens in signifier itself. Therefore, there is no other content other than representation action. It means that representation is referred to representation itself and the representation action is also introduces as an image.

In this field Foucault says: "an idea can be a signature for another idea, not only because representation attachment can be created between them, but also because representation can be always represented in an idea that is under representation or since representation is always perpendicular on its own in its specific nature" ${ }^{\prime 28}$. It means that representation is apparently an object; although representation refers to its own. Hence, in regard with defining signature in classic era and its relationship with representation, it could be mentioned that signature has the ability of representation. However, the capability is in fact the capability of representing the representation. Therefore, the signified in nothing unless analysis of signature itself. Foucault says about semiotic in classic era: "as system refers to something that is signified, it grants no different nature given to signature. Hence, meaning can be nothing more than generality of signatures that are arranged" ${ }^{29}$.

Manner of representation of signature in classic era can be stated as follows: classic man has observed signature and object once alongside and hence, he considers signature as the representation factor of signified contractually. However, signature is not like signified at all. As a result, the thing remained is same representative feature of signature that is free of any kind of content. Accordingly, the remained thing is representation action and not representation of something and the representation action is something that is emerged. The action could be observed clearly in Velázquez's Las Meninas. In this work, representation is illustrated in best manner. In other words, the painting is nothing unless representation action, along with absence of signified.

Absence of signified in Velázquez's Las Meninas

Foucault has considered Velázquez's Las Meninas (figure 3) as the representative of the mindset of classic era and has introduced representation as the clear feature of this work. The Velázquez himself is observable in painting while drawing a big painting, a painting that its back is illustrated in picture and no one can see the canvas. This is same place that is being represented on the canvas. However, it should be noted that not only the image on the canvas, nut also the place focused by painter is not specified and clear $^{30}$.

Therefore, it could be mentioned that a painting, in which painter is representing a scene, is intangible for double. This is because; on one hand, one can't see the face of painting that what is on it and on the other hand, the landscape that painter is stared to it is not clear for the viewer. The view is exactly same blind spot where an essential hiding factor is existed, in which our look can be disappeared ${ }^{31}$. As a result, the only thing cleared for audiences from representation action of painter if a scene, in which the painter is stood up in front of his painting and represents something. This issue that view can't observe representation scene returns to knowledge system of classic era, according to which the thing is being represented can never be appeared ${ }^{32}$. In regard with the absence, it was explained before that how signature used to do just representation action in classic era. As a result, in this painting, only this issue can be cleared that something is being represented. However, in order to find that what the painter is

\footnotetext{
${ }^{28}$ Foucault, 2010: 135

${ }^{29}$ Foucault, 2010: 137

${ }^{30}$ Borne, 1999: 1181

${ }^{31}$ Foucault, 2010: 33

${ }^{32}$ Boyne, 2002:347
}

Submit Date: 11.06.2016, Acceptance Date: 15.07.2016, DOI NO: 10.7456/1060AGSE/056

Copyright (C) The Turkish Online Journal of Design, Art and Communication 
drawing, viewer should see the surface of canvas face to painter. This is impossible based on classic episteme.

A point that should be referred here is that painter is stared on us and the space that audiences are placed. It seems that painter is representing audiences in his painting. Here, mutual interaction of signifier and signified of classic era could be observed: our look and painter's look. When watching the painting, painter is also watching us. The other interaction can be found in this issue that at the same time, painter looks at audiences and leaves them at the moment and replaced them with the thing that has been always there before audiences are present there (the pattern itself) ${ }^{33}$. The interaction between audiences and pattern is constantly changing.

The absence in this painting (absence of signified) is very important, since in thought of classic era, the person, to whom the representation is done, had no position in knowledge system of renaissance. With the language structure, natural history and analysis of wealth for human was vital. However, no epistemological awareness is in hand about human. Hence, in classic thought, nothing is observed under the title of "human knowledge". This is because; it had no place as an object for knowledge and only after end of thinking system of classic era, human is emerged as the object of epistemology. Hence, Foucault considers human as a new invention: "for sure, it could be mentioned that human could be disappeared as an image on the seashore" ${ }^{34}$.

In this painting, audiences are observing this issue that when the painter is stared on them and is drawing their picture, he can't see his own image. As Foucault refers in analysis of Don Quixote; although he has read many new stories and narrated them, he has not read his book and can't read it, since he has been represented through his book. Hence, as according to knowledge system of classic era Don Quixote was unable to read his book, audiences in Velazquez's "Las Meninas" are unable to see their own representation.

Another important issue is that in classic thought, representation is illustrated in signature; meaning that in classic thought, the thing that is represented is considered as signature and signature has no content other than representation action. More interestingly, according to this episteme, the signified is nothing other than the thing represented. Therefore, a scene is observable in this painting, in which a representation action is being done. Painter has a brush in his hand and is drawing a painting. The painter is representing something on the canvas. However, all thing observed from this action is just representation action.

This issue can be observed clearly in "Las Meninas" by Velazquez. Accordingly, one can speak just about a model and consider it. According to classic semiotic system, the signified is nothing other than representation done by painter. Hence, representation refers to itself and the remained thing is same representation action as an image.

On the wall, there is a mirror that pictures portrait of Philip IV and his wife, Mariana. It seems that painter is drawing their picture on the canvas. However, the represented picture in mirror can't be considered as an image, since the image is a legend in view of Foucault that confuses audiences and among all representations; the image is the only image that is observable. No one looks at the mirror, even Philip IV and his wife, Mariana don't look at the mirror, but instead they look at people at the room. Therefore, the mirror illustrates an important indifference in classic era. Mirror pictures classic era with inattention to all objects and people in the room. By that era, they believed that if people separate themselves from all subjective presumptions and emotions while looking at objects, they can perceive objects. In aesthetic domain of classic era, an impartial attitude free from any kind of intention to natural aesthetics and artistic

\footnotetext{
${ }^{33}$ Foucault, 2010: 34

${ }^{34}$ Wickes, 2007: 114
}

Submit Date: 11.06.2016, Acceptance Date: 15.07.2016, DOI NO: 10.7456/1060AGSE/056

Copyright (C) The Turkish Online Journal of Design, Art and Communication 
works was prevailed. Kant's Critique of Judgment power can be clear example of this attitude. Accordingly, mirror in this work indicates impartial viewpoint in classic era ${ }^{35}$.

It could be mentioned that Velazquez's "Las Meninas" is representation of classic era representation, in which Foucault has specified his main characteristics in representation and has analyzed thinking structure of a historical age. The painting and its narration of representation is in such manner that it seems that classic era has represented itself through the painting. However, the main feature of classic era observed in this painting in view of Foucault is the character, for which representation is performed. In classic thought, represented character and the person, who has identified him/herself as image or reflection can never found in the table. Before the end of $18^{\text {th }}$ century, no human was existed ${ }^{36}$.

\section{CONCLUSION}

Foucault has considered artistic works as representative of thinking domain of a historical era. Hence, artistic works can show thinking features an episteme. As artistic works have an inseparable attachment to historical-social context and gain their identity from it, it could be mentioned that trough analyzing artistic works and assessing actions and interactions of different discourses of an era, not only reason for emergence of specific issue can be identified, but also thought of a historical period can be also cleared through artistic work. Hence, Foucault considers an inseparable attachment between artistic work and epistemology.

\section{REFERENCES}

Smart, Barry, Michel Foucault, trans. Leyla Joafshani and Hasan Chavoshian, Ameh Publication, Tehran, 2006

Foucault, Michel, order of speech, trans. Bagher Parham, Agah Publications, Tehran, 1999

Foucault, Michel, The Order of Things, trans. Y. Emami, Cultural Studies and Social Research Institute, Tehran, 2010

Foucault, Michel, History of Madness, trans. F. Valian, Hermes Publications, Tehran, 2006

Foucault, Michel, Theater of philosophy, trans. Afshin Jahandideh and Nikoo Sarkhosh, Ney publication: Tehran, 2011

Foucault, Michel, Archeology of knowledge, trans. Abdulghader Savari, Publications of Gam-e Nou: Tehran, 2009

Foucault, Michel, This is not a pipe, trans. Mani Haghighi, publishing center: Tehran, 2009

Mills, Sara, discourse, translation Fattah Mohammadi, the publication of the third millennium: Zanjan, 2009

----, ---, Michel Foucault, trans. Darush Noori, publishing center, Tehran, 2010

Hubert Dreyfus and Poul Rabinow, Michel Foucault beyond structuralism and hermeneutics, trans. Hussein Bashiriyeh, Ney Publishing: Tehran, 2010

Gilirmeh, Merquer, Jose, Michel Foucault, the trans. Nazi Azima, Karnameh Press: Tehran, 2010

Chandler, Daniel, Foundations of Semiotics, trans. Mehdi Parsa, Publishing Institute of Islamic culture and art: Tehran, 1998

Brace Gat and Dominique Lewis MacIver, Encyclopedia of Aesthetics, Art Academy Publications, Tehran, 2007

Tanke, Joseph J, Foucault's Philosophy of Art, Continuum, New York, 2009

Borne, Harold, The Oxford Companion to Art, Oxford, 1999

Myer, Bernard L, The Macmilian Encyclopedia of Art, Coplestone, 2001

Boyne, Roy, A Companion to Art Theory, Blackwell,2002

Alec McHoul and Wendy Grace, A Foucault Primer, Routledge, London, 1993

Michel, Foucault, The order of Things: An Archeology of the Human Sciences, Vintage Books, New York, 1994

${ }^{35}$ Refer to: Wickes, 2007, 110

${ }^{36}$ Foucault, 2010: 519

Submit Date: 11.06.2016, Acceptance Date: 15.07.2016, DOI NO: 10.7456/1060AGSE/056

Copyright (C) The Turkish Online Journal of Design, Art and Communication 